\title{
Reaction of melon genotypes to the gummy stem blight and the downy mildew
}

\author{
Gil R dos Santos ${ }^{1}$; Manoel D de Castro Neto'; Leandro N Ramos²; Adalberto C Café-Filho²; Ailton \\ Reis $^{3}$; Valéria G Momenté ${ }^{1}$ Joenes M Pelúzio; Maíra Ignácio \\ ${ }^{1}$ Universidade Federal do Tocantins, C. Postal 66, 77402-970 Gurupi-TO; ${ }^{2}$ UnB-Dep ${ }^{\text {to }}$ Fitopatologia, 70910-900 Brasília-DF; ${ }^{3}$ Embrapa \\ Hortaliças, C. Postal 218, 70359-970 Brasília-DF; gilrsan@uft.edu.br
}

\begin{abstract}
The gummy stem blight (Didymella bryoniae) and the downy mildew (Pseudoperonospora cubensis) are two foremost melon (Cucumis melo) diseases, considering their effects on yield and fruit quality. Despite the importance of such diseases, relatively few studies have been done so far on the identification of resistance sources to D. bryoniae and P. cubensis in Brazil. This work aimed at evaluating the resistance of commercial melon genotypes to the gummy stem blight and the downy mildew. Firstly, the most aggressive and representative $D$. bryoniae isolate was selected. Subsequently, the resistance of 86 melon genotypes to stem infection was studied upon greenhouse conditions by inoculating with the previously selected isolate. Afterwards, the resistance to mildew and leaf infection by $D$. bryoniae of 28 melon genotypes was evaluated in the field, under natural infection. In the greenhouse, all 86 melon genotypes were infected and showed stem infection symptoms caused by $D$. bryoniae four days after inoculation. Nevertheless, a significant variation on the resistance levels of the melon genotypes was found. Under field conditions and natural inoculation, genotypes Taslaki and Sary Juliabi were the most susceptible to leaf infection by $D$. bryoniae, significantly differing from the other genotypes. The lowest levels of susceptibility were identified in genotypes Perlita Busle S1, Valenciano Elíptico, Glaver, MR1, and 2526. All genotypes were susceptible to the downy mildew, albeit differing in susceptibility levels.
\end{abstract}

Keywords: Cucumis melo, Didymella bryoniae, Pseudoperonospora cubensis, genetic resistance.

\section{RESUMO}

\section{Reação de genótipos de melão ao crestamento gomoso e ao} míldio

O crestamento gomoso do caule (Didymella bryoniae) e o míldio (Pseudoperonospora cubensis) estão entre as principais doenças do meloeiro (Cucumis melo) ocasionando redução da produtividade e da qualidade dos frutos. Apesar da importância dessas doenças, são poucos os trabalhos envolvendo a identificação de fontes de resistência a D. bryoniae e a $P$. cubensis no Brasil. O objetivo deste trabalho foi avaliar a resistência de genótipos comerciais de melão a essas doenças. A partir da seleção de um isolado mais agressivo, foi estudada, em condições de casa de vegetação, a resistência de 86 genótipos de meloeiro à infecção por $D$. bryoniae no caule. Posteriormente, em condições de campo, foi avaliada a resistência conjunta de 28 genótipos ao crestamento gomoso e ao míldio. Em casa de vegetação, todos os 86 genótipos de meloeiro avaliados foram infectados e mostraram sintomas de crestamento no caule, quatro dias após a inoculação. Houve variação significativa nos níveis de resistência entre os genótipos avaliados. No campo, sob inóculo natural, os genótipos Taslaki e Sary Juliabi mostraram-se mais suscetíveis à infecção por D. bryoniae nas folhas, diferindo significativamente dos demais genótipos. Os menores níveis de suscetibilidade foram verificados nos genótipos Perlita Busle S1, Valenciano Elíptico, Glaver, MR1 e 2526. Na avaliação da resistência ao míldio, todos os genótipos foram considerados suscetíveis, embora tenham sido encontradas diferenças nos níveis de suscetibilidade.

Palavras-chave: Cucumis melo, Didymella bryoniae, Pseudoperonospora cubensis, resistência genética.

(Recebido para publicação em 29 de abril de 2008; aceito em 7 de abril de 2009)

(Received in April 29, 2008; Accepted in April 7, 2009)

$\mathrm{T}$ he cultivation of melon (Cucumis melo L.) in Brazil has a mounting economic importance due mainly to the opportunities opened by the external market. The Brazilian Northeastern region hosts over $90 \%$ of the melon fields, as well as of the national production (Santos et al., 2004). In this region, high temperatures and profuse insolation promote the development of fruits with high contents of soluble solids. In the State of Tocantins, where melon also founds favorable soil and climatic conditions, crops are expanding gradually from the current fields grown by small farmers.
In spite of the suitable environmental conditions, the lack of cultivars with resistance to the most important diseases hampers the expansion of melon cultivation in Tocantins. The gummy stem blight or stem canker, induced by the fungus Didymella bryoniae (Fuckel) Rehm, ranks among the leading melon diseases due to the setback it causes in both fruit yield and quality (Santos \& Café Filho, 2006). The gummy stem blight is a common disease in tropical and subtropical areas worldwide (Sitterly \& Keinath, 1996). The downy mildew, whose etiological agent is Pseudoperonospora cubensis (Berk. et
Curtis) Rostowzew, is another ordinary, but relevant disease in melon. The downy mildew may give grounds to field total losses, mainly when rainy conditions co-occur with cool temperatures (Blancard et al., 1996). According to Rego (1995), wind, rain drops, and sprinkler irrigation are responsible for $P$. cubensis dissemination. Sporangia are driven far away by the wind. The pathogen infects the majority of the species in family Cucurbitaceae, both cultivated, such as watermelon (Citrullus lanatus (Thunb.) Matsum. \& Nakai), and weeds. Under the Tocantins environmental conditions, 
the pathogen is challenging mainly in July, when the temperature falls from $35^{\circ} \mathrm{C}$ during the day to $25^{\circ} \mathrm{C}$ at night, and leaf wetting simultaneously takes place (Santos et al., 2005). At present, control measures are based on fungicide spraying. However, the efficacy of chemical control is very restricted in highly susceptible cultivars and when meteorological conditions are favorable to the pathogen (Thomas, 1998).

There are few reports on the identification of sources of resistance to D. bryoniae and P. cubensis in Brazil. In an experiment carried out at the greenhouse and under plastic tunnel to evaluate the resistance to $D$. bryoniae in two half-sib populations derived from genotypes PI 140471 and Anô\#2, both progenies were more resistant than the reference cultivar. Nevertheless, cultivar Anô\#2 was considered a more adequate resistance source, since it concurrently assembles multiple disease resistance and favorable commercial characteristics (Tsutsumi \& Silva, 2004). The resistance of PI 140471, a Texan native melon, is controlled by a pair of genes (Norton \& Prasad, 1967). The resistance to $D$. bryoniae in melon cultivars Anô\#1, Anô\#2, and Anô\#3, was introgressed from cultivar Mi-tang-ting (Takada, 1983). Other researchers have demonstrated that the moderate resistance in lines $\mathrm{C \# 1}$ e $\mathrm{C \# 8}$, derived from the melon cultivar Auburn Cantaloup, was controlled by an independent pair of genes. Accessions PI 157082 and PI 511890 own their resistance to the gummy stem blight to a single dominant gene (Zuniga et al., 1999). The yellow melon genotype PI $124111 \mathrm{~F}$, native from India, displayed resistance to all pathotypes of $P$. cubensis. The resistance is controlled by two complementary loci with partial dominance (Cohen \& Eyal, 1987; Thomas et al., 1988).

Considering the importance of the gummy stem blight and the downy mildew in the melon agribusiness and the scarce research efforts on studying the reaction of commercial resistance sources to both diseases, the aim of this work was to evaluate the resistance of commercial melon genotypes to the gummy stem blight and the downy mildew.
Table 1. Aggressiveness of Didymella bryoniae isolates to melon seedlings, cultivars Dalton and Solarking, assessed as the average length of the stem lesion, four days after inoculation (agressividade de isolados de Didymella bryoniae a plântulas de melão, cultivares Dalton e Solarking, avaliada de acordo com o comprimento médio da lesão no caule do hospedeiro, quatro dias após a inoculação). Gurupi, UFT, 2007.

\begin{tabular}{lcc}
\hline \multirow{2}{*}{ Isolate } & \multicolumn{2}{c}{ Lesion Class* $^{*}$} \\
\cline { 2 - 3 } & cv. Dalton & cv. Solarking \\
\hline BRSb & +++ & ++ \\
78 & ++ & + \\
MGP & ++ & + \\
BRSc & + & + \\
76 & + & + \\
BRSa & + & + \\
CNPH & + & + \\
\hline
\end{tabular}

*Scale for lesion classes (escala para classe de lesão): (-) symptonless seedlings (plântula sem sintomas), (+) seedlings with lesions shorter than $1 \mathrm{~cm}$ (lesão menor que $1 \mathrm{~cm}),(++)$ seedlings with lesions longer than $1 \mathrm{~cm}$ (lesão maior que $1 \mathrm{~cm}),(+++)$ seedlings showing damping-off (tombamento da plântula).

\section{MATERIAL AND METHODS}

Assay I: Aggressiveness of Didymella bryoniae isolates to melon seedlings - In this assay, we used seven $D$. bryoniae isolates. Isolates were obtained from melon plants with the gummy stem blight symptoms and conserved in PDA medium (250 g of potato $+15 \mathrm{~g}$ of dextrosis $+20 \mathrm{~g}$ of agar) at the Mycological Collections of the University of Brasília and Embrapa Vegetables. Aiming at standardizing the aggressiveness potential of the isolates, which were kept in vitro for different periods at the Collections, all isolates used in this study were inoculated in 20-day old melon seedlings, cultivar Dalton. Before inoculation, isolates were cultured in PDA medium and incubated for ten days. For inoculation, mycelium disks with $0.6-\mathrm{cm}$ in diameter, taken from the inner part of the colony, were fixed to the seedling stem $3.0 \mathrm{~cm}$ over soil level, using a sterile pin. After inoculation, seedlings were incubated for $48 \mathrm{~h}$ in a moist chamber, with 12-hour photoperiod and temperature ranging from 28 to $33^{\circ} \mathrm{C}$.

For studying isolate aggressiveness, we used only colonies developed out of re-isolation from the abovementioned inoculated plants. Experiments were carried out at the greenhouse, with temperatures also ranging between 28 and $33^{\circ} \mathrm{C}$. Seedlings grew in $4.0-\mathrm{kg}$ polyethylene pots, filled with a $3: 1$ mixture of vegetal mold + manure. We sowed six seeds per pot of cultivars Solarking and Dalton, thinning to the four most uniform plants. Pots were irrigated daily to keep the soil constantly moist.

To study isolate aggressiveness, sensu Andrivon (1993), the experiment was set in a completely randomized design, with seven treatments and three replications. Treatments corresponded to the following $D$. bryoniae isolates: Melon Brasília a (BRSa), Melon Brasília b (BRSb), Melon Brasília c (BRSc), Melon DF1 (76), Melon DF2 (78), Melon Gurupi (MGP), and CNPH. The experimental plot consisted of a 4-plant pot, with each plant taken as a subsample. Isolate aggressiveness was assessed by measuring the length of the stem lesion four days after inoculation. To select isolates, we used the methodology established by Santos (2005), according to the following scale: (-) symptomless seedlings, (+) seedlings with lesions shorter than $1 \mathrm{~cm},(++)$ seedlings with lesions longer than $1 \mathrm{~cm}$, $(+++)$ seedlings showing damping-off.

Assay II: Resistance of melon genotypes to Didymella bryoniae stem infection - The resistance of 86 melon genotypes to $D$. bryoniae was challenged at the greenhouse, with temperatures varying from 28 to $33^{\circ} \mathrm{C}$. Plants grew in 3.0 L-pots, filled with a $3: 1$ mixture of vegetal mold + manure. 
Table 2. Resistance of melon genotypes to the stem inoculation of Didymella bryoniae, assessed as the average length of the stem lesion, four days after inoculation (resistência de genótipos de melão à inoculação no caule de Didymella bryoniae, avaliada pelo comprimento médio da lesão, quatro dias após a inoculação). Gurupi, UFT, 2007.

\begin{tabular}{|c|c|c|}
\hline Genotype* & Origin & Lesion Length $(\mathrm{cm})^{* *}$ \\
\hline Hegykô & Hungary & $1,4 \mathrm{c}$ \\
\hline M63A17 & Spain & $1,4 \mathrm{c}$ \\
\hline Melão Caboclo & Ceasa-DF1 & $1,4 \mathrm{c}$ \\
\hline $\mathrm{M} 59 \mathrm{CH} 4$ & Spain & $1,4 \mathrm{c}$ \\
\hline Valenciano Elíptico & Brasília & $1,4 \mathrm{c}$ \\
\hline Sary Juliabi & The Soviet Union & $1,5 \mathrm{c}$ \\
\hline Hales Best Jumbo & IPB Seeds & $1,5 \mathrm{c}$ \\
\hline Glaver & Japan & $1,5 \mathrm{c}$ \\
\hline Amarelo & Commercial & $1,5 \mathrm{c}$ \\
\hline F1 Helios & Cotia County - SP & $1,5 \mathrm{c}$ \\
\hline Valenciano Amarelo & Commercial & $1,5 \mathrm{c}$ \\
\hline PS-2 Pele de Sapo & Spain & $1,5 \mathrm{c}$ \\
\hline 2526 & German & $1,5 \mathrm{c}$ \\
\hline Sea Bolt & Japan & $1,5 \mathrm{c}$ \\
\hline Eldorado & Embrapa Vegetables & $1,5 \mathrm{c}$ \\
\hline MelãoTrevo & Commercial & $1,5 \mathrm{c}$ \\
\hline Taslaki & The Soviet Union & $1,5 \mathrm{c}$ \\
\hline Csárdaszállás & Hungary & $1,5 \mathrm{c}$ \\
\hline Prince & USDA/USA & $1,5 \mathrm{c}$ \\
\hline A2 & Spain & $1,5 \mathrm{c}$ \\
\hline A1 & Spain & $1,5 \mathrm{c}$ \\
\hline Nyíregyháza & Hungary & $1,5 \mathrm{c}$ \\
\hline Dolidor F1 & Netherlands & $1,5 \mathrm{c}$ \\
\hline MR 1 & USDA/USA & $1,5 \mathrm{c}$ \\
\hline Aroma F1 & Wisconsin University & $1,5 \mathrm{c}$ \\
\hline Uc. Perlita Busle S1 & Wisconsin University & $1,5 \mathrm{c}$ \\
\hline Gold Beauty & USA & $1,5 \mathrm{c}$ \\
\hline Caipira & Currais Novos County - RN & $1,6 \mathrm{c}$ \\
\hline Kzil & The Soviet Union & $1,6 \mathrm{c}$ \\
\hline IC-Kzil & The Soviet Union & $1,6 \mathrm{c}$ \\
\hline Galileu & Comercial & $1,6 \mathrm{c}$ \\
\hline Polpa Laranja & Brasília - DF & $1,6 \mathrm{c}$ \\
\hline Nyíribrony & Hungary & $1,6 \mathrm{c}$ \\
\hline Galia F1 & Topseed & $1,6 \mathrm{c}$ \\
\hline Ananás & Germany & $1,6 \mathrm{c}$ \\
\hline Gaucho & Sakata & $1,6 \mathrm{c}$ \\
\hline Gynox Resist. P. & Wisconsin University & $1,6 \mathrm{c}$ \\
\hline Nagycserkesz & Hungary & $1,6 \mathrm{c}$ \\
\hline PS-1 Pele de Sapo & Spain & $1,6 \mathrm{c}$ \\
\hline 193246 & Pelotas County - RS & $1,6 \mathrm{c}$ \\
\hline TM-002-F1 & Japan & $1,6 \mathrm{c}$ \\
\hline TM-001-F1 & Japan & $1,6 \mathrm{c}$ \\
\hline Flexuosus "M-2791" & Israel & $1,6 \mathrm{c}$ \\
\hline Chilton & Wisconsin University & $1,6 \mathrm{c}$ \\
\hline Cristobal & Asgrow & $1,6 \mathrm{c}$ \\
\hline Shavit Hibrid & Israel & $1,6 \mathrm{c}$ \\
\hline M53A2 & Spain & $1,6 \mathrm{c}$ \\
\hline 193254 & Canguçu County - RS & $1,6 \mathrm{c}$ \\
\hline 2534 & Germany & $1,7 \mathrm{~b}$ \\
\hline Valenciano Redondo & Brasília - DF & $1,7 \mathrm{~b}$ \\
\hline Melão Caipira & Brasília - DF & $1,7 \mathrm{~b}$ \\
\hline
\end{tabular}

The experiment was planned in a completely random design, with 86 treatments (Table 2), and three replications. We used isolate $D$. bryoniae BRSb, selected due to its comprehensive representation (Santos et al., 2008), higher aggressiveness, and uniform results, according to the outcomes of the aggressiveness assay (Table 1). Inoculation and incubation of inoculated seedlings, as well as lesion evaluation, were performed as described for assay 1.

Assay III: Field resistance of melon genotypes to the gummy stem blight and the downy mildew - We used the 28 melon genotypes most resistant to the gummy stem blight in the greenhouse to evaluate the joint resistance to this disease and to the downy mildew in the field (Table 3). The experiment was carried out from January to March 2007 , in Gurupi county, State of Tocantins, at the experimental station of the Federal University of Tocantins (11 $43^{\circ}$ ' $45^{\prime \prime} \mathrm{S}$; 4904'07" W, 280 m over sea level). The experimental area was previously used for growing watermelon and had a history of occurrence of both the gummy stem blight and the downy mildew. Melon plants grew under natural disease pressure, upon the existing field inoculum. The experiment was designed in completely randomized blocks, with 28 treatments and three replications. In each plot, twelve plants were assessed.

After plowing and harrowing, the experimental area was fertilized $(800 \mathrm{~kg}$ $\mathrm{ha}^{-1}$, formulation 05-25-15 of N-P-K). Seeds were sown in holes, in $1.0 \times 0.5 \mathrm{~m}$ spacing, placing 5 seeds hole ${ }^{-1}, 2 \mathrm{~cm}$ deep. Each experimental plot consisted of six holes planted with the same cultivar. Thinning was carried out 30 days after emergence (DAE), leaving two plants hole ${ }^{-1}$, with side fertilization performed along (200 kg ha-1, formulation N-P-K 20-00-20). Weeding was carried out three times during the whole experiment, 10, 20, and $30 \mathrm{DAE}$, through hand-hoeing. Plants were rainfed, except for a two-day period without rain, when sprinkler irrigation was used with 12-h shifts and a $7.9 \mathrm{~mm}$ average daily depth. Metamidophos at $0.24 \mathrm{~kg}$ $\mathrm{ha}^{-1}$, applied 20, 30, and 45 DAE, was used for controlling pests. No fungicides were sprayed. 
The gummy stem blight and the downy mildew were assessed in leaves 75 DAE, when both diseases were spread uniformly. Diseases were evaluated based on the following scale (Santos et al., 2005): $0=$ healthy plant; $1=$ less than $1 \%$ of affected leaf area; $3=$ between 1 and $5 \%$ of affected leaf area; $5=$ between 6 and $25 \%$ of affected leaf area; $7=$ between 26 and $50 \%$ of affected leaf area; $9=$ more than $50 \%$ of affected leaf area. In view of the co-occurrence of both diseases, symptom differentiation was based on the lesion general aspect, according to Blancard et al. (1996). The gummy stem blight symptoms were recognized as dark necrotic spots, in which the damaged tissue dries and get loose from the plants. The downy mildew symptoms were identified as angular or round spots that progress from light green to necrosis, displaying the fungi light reproductive structures in the abaxial leaf surface. To support the visual diagnosis, infected leaves were collected and examined under optical and stereoscopic microscope to confirm the presence of either pathogen. Data were submitted to analysis of variance and the means for genotypes were separated using the Scott-Knott test. We used the software ASSISTAT 7.4 beta2007 (Silva \& Azevedo, 2006).

\section{RESULTS AND DISSCUSSION}

Assay I: Aggressiveness of Didymella bryoniae isolates to melon seedlings - All isolates were pathogenic to melon seedlings, cultivars Dalton and Solarking. Nevertheless, isolates differed from each other in aggressiveness, sensu Andrivon (1993). Isolate BRSb was the most aggressive, since it induced damping-off in cultivar Dalton seedlings and caused an average stem lesion longer than $1 \mathrm{~cm}$ in cultivar Solarking seedlings (Table 1). This isolate belongs to the diversity group which is prevalent in Brazil (Santos et al., 2008) and may well be employed in melon breeding programs for resistance to the gummy stem blight. Cultivar Solarking was less susceptible than cultivar Dalton for three out of the seven isolates studied.

Assay II: Resistance of melon genotypes to Didymella bryoniae stem infection - All genotypes were infected

Table 2. Part II

\begin{tabular}{|c|c|c|}
\hline Genotype* & Origin & Lesion Length $(\mathrm{cm})^{\star *}$ \\
\hline Sib do CNPH 82-038 & Dessert Seed & $1,7 b$ \\
\hline Janne Canari & Petoseed & $1,7 \mathrm{~b}$ \\
\hline Honey Dew Green & Petoseed & $1,7 \mathrm{~b}$ \\
\hline W6 & Wisconsin University & $1,7 \mathrm{~b}$ \\
\hline Asgrow 200230 & USA & $1,7 \mathrm{~b}$ \\
\hline Deltex & Commercial & $1,7 \mathrm{~b}$ \\
\hline W 30 & Japan & $1,7 \mathrm{~b}$ \\
\hline PMR-45 & Petoseed & $1,7 \mathrm{~b}$ \\
\hline Karry Kiz & The Soviet Union & $1,7 \mathrm{~b}$ \\
\hline Honi Deni Hami & China & $1,7 \mathrm{~b}$ \\
\hline 193249 & Piratini County - RS & $1,7 \mathrm{~b}$ \\
\hline Edisto 47 & Wisconsin University & $1,7 \mathrm{~b}$ \\
\hline Doublon & Commercial & $1,7 \mathrm{~b}$ \\
\hline Golden & Petoseed & $1,7 \mathrm{~b}$ \\
\hline Miskolc & Hungary & $1,7 \mathrm{~b}$ \\
\hline TR 63230 & Turkey & $1,7 \mathrm{~b}$ \\
\hline Verde Comprido & Spain & $1,7 \mathrm{~b}$ \\
\hline Super Doce & Spain & $1,7 \mathrm{~b}$ \\
\hline Sul & State of Rio Grande do Sul & $1,8 \mathrm{~b}$ \\
\hline Pinonet & France & $1,8 \mathrm{~b}$ \\
\hline Attajskaja & Embrapa GR\&B2 & $1,8 b$ \\
\hline Glover & Japan & $1,8 \mathrm{~b}$ \\
\hline 193248 & Piratini County - RS & $1,8 \mathrm{~b}$ \\
\hline Margot & France & $1,8 b$ \\
\hline Marigold & USA & $1,8 \mathrm{~b}$ \\
\hline 193258 & Rio Grande County - RS & $1,9 \mathrm{a}$ \\
\hline Rochedo & Asgrow & $1,9 \mathrm{a}$ \\
\hline Koh & Japan & $1,9 \mathrm{a}$ \\
\hline G-35 & Japan & $1,9 \mathrm{a}$ \\
\hline Gold Mine & Petoseed & $1,9 \mathrm{a}$ \\
\hline Extra Supermercado & Brasília - DF & $1,9 \mathrm{a}$ \\
\hline PI 532830- & China & $2,0 \mathrm{a}$ \\
\hline Caipira da Bolívia & Bolivia & $2,0 \mathrm{a}$ \\
\hline Ak-Kaun & The Soviet Union & $2,1 \mathrm{a}$ \\
\hline 193257 & Rio Grande County - RS & $2,1 \mathrm{a}$ \\
\hline CV\% & & 9,7 \\
\hline
\end{tabular}

*Seedlings inoculated by a stem wound, 20 days after emergence (plântulas inoculadas com ferimento no caule, 20 dias após a emergência); **Means followed by the same letter in the column do not significantly differ from each other, Scott-Knott clusteting test, $\mathrm{p}<0.05$ (médias seguidas da mesma letra nas colunas não diferem entre si, teste de agrupamento de Scott-Knott, p<0,05).

${ }^{1}$ CEASA-DF $=$ Wholesale market for Brasília-DF (Central de Abastecimento de BrasíliaDF); ${ }^{2}$ Embrapa GR\&B= Embrapa Genetic Resources and Biotechnology (Embrapa Recursos Genéticos e Biotecnologia).

upon stem inoculation and presented characteristic symptoms four days after inoculation. In spite of the inexistence of immunity, significant variation in susceptibility to stem infection was observed among the inoculated genotypes. Within 86 genotypes, 48 had stem lesions ranging from 1.4 to $1.6 \mathrm{~cm}$; 28 , from 1.7 to $1.8 \mathrm{~cm}$; and 10 , from 1.9 to
$2.1 \mathrm{~cm}$, the latter ones clustered as the most susceptible. The genotypes with the shortest stem lesions were M59CH4, Valenciano Elíptico, Melão Caboclo, M63A17, and Hegykô. The most susceptible genotypes, with the longest stem lesions, were 193257, AK-Kaun, Caipira da Bolívia, and PI 532830 (Table 2). In watermelon, Santos \& Café-Filho 
Table 3. Field resistance of 28 melon genotypes to the gummy blight (Didymella bryoniae) in leaves and to the downy mildew (Pseudoperonospora cubensis) (resistência em campo de 28 genótipos de melão ao crestamento gomoso (Didymella bryoniae) e ao míldio (Pseudoperonospora cubensis)). Gurupi, UFT, 2007.

\begin{tabular}{|c|c|c|}
\hline \multirow{2}{*}{ Genotypes } & \multicolumn{2}{|c|}{ Disease Severity* } \\
\hline & Gummy blight in leaves & Downy mildew \\
\hline Perlita Busle S1 & $3.6 \mathrm{c}$ & $4.3 \mathrm{~b}$ \\
\hline Valenciano Elíptico & $3.6 \mathrm{c}$ & $5.0 \mathrm{a}$ \\
\hline Glaver & $3.6 \mathrm{c}$ & $5.6 \mathrm{a}$ \\
\hline MR1 & $3.6 \mathrm{c}$ & $7.6 \mathrm{a}$ \\
\hline 2526 & $3.6 \mathrm{c}$ & $7.6 \mathrm{a}$ \\
\hline $\mathrm{M} 59 \mathrm{CH} 4$ & $4.3 \mathrm{c}$ & $6.3 \mathrm{a}$ \\
\hline Hegykô & $4.3 \mathrm{c}$ & $6.3 \mathrm{a}$ \\
\hline Aroma F1 & $4.3 \mathrm{c}$ & $4.3 \mathrm{~b}$ \\
\hline Melão Caboclo & $4.3 \mathrm{c}$ & $3.6 \mathrm{~b}$ \\
\hline Csardaszallas & $4.3 \mathrm{c}$ & $5.6 \mathrm{a}$ \\
\hline $\mathrm{M} 88 \mathrm{CH} 4$ & $4.3 \mathrm{c}$ & $3.6 \mathrm{~b}$ \\
\hline Valenciano Amarelo & $4.3 \mathrm{c}$ & $7.6 \mathrm{a}$ \\
\hline Gold Beauty & $4.3 \mathrm{c}$ & $6.3 \mathrm{a}$ \\
\hline M63A17 & $5.0 \mathrm{c}$ & $6.3 \mathrm{a}$ \\
\hline F1 Helios & $5.0 \mathrm{c}$ & $5.0 \mathrm{a}$ \\
\hline P S-2 Pele de Sapo & $5.0 \mathrm{c}$ & $6.3 \mathrm{a}$ \\
\hline A2 & $5.6 \mathrm{c}$ & $6.3 \mathrm{a}$ \\
\hline Hales Best Jumbo & $5.6 \mathrm{c}$ & $5.6 \mathrm{a}$ \\
\hline Amarelo & $5.6 \mathrm{c}$ & $5.0 \mathrm{a}$ \\
\hline Prince & $5.6 \mathrm{c}$ & $3.6 \mathrm{~b}$ \\
\hline Nyiregyhara & $5.6 \mathrm{c}$ & $6.3 \mathrm{a}$ \\
\hline Sea Bolt & $6.3 \mathrm{~b}$ & $7.0 \mathrm{a}$ \\
\hline Dolidor F1 & $6.3 \mathrm{~b}$ & $5.6 \mathrm{a}$ \\
\hline Melão Trevo & $6.3 \mathrm{~b}$ & $5.0 \mathrm{a}$ \\
\hline A 1 & $7.0 \mathrm{~b}$ & $5.6 \mathrm{a}$ \\
\hline Eldorado & $7.6 \mathrm{~b}$ & $5.6 \mathrm{a}$ \\
\hline Taslaki & $9.0 \mathrm{a}$ & $3.0 \mathrm{~b}$ \\
\hline Sary Juliabi & $9.0 \mathrm{a}$ & $5.6 \mathrm{a}$ \\
\hline CV\% & 11,3 & 10,8 \\
\hline
\end{tabular}

*Prior to the application of the means separation test, raw data were tranformed to $\mathrm{X}=$ " $\mathrm{x}+$ 0,5 (antes da aplicação do teste de médias, os dados originais foram transformados para X=" $\mathrm{X}$ $+0,5)$. Means followed by the same letter in the column do not differ significantly from each other, Scott-Knott clustering test, $\mathrm{p}<0.05$ (médias seguidas da mesma letra nas colunas não diferem significativamente entre si, teste de agrupamento de Scott-Knott, $\mathrm{p}<0,05$ ).

(2005) also found variability in the reaction to the gummy stem blight from cultivar to cultivar. The protection against the disease given by genetic resistance, although only partial, decreases the outbreak progress rate and is valuable in association with other measures, contributing to the reduction in both the use of fungicides and production costs. Genetic resistance can also be useful to lessen chances of environmental contamination, accidents with the person in charge of spraying, and presence of chemical residues in fruits.
Assay III: Field resistance of melon genotypes to the gummy blight in leaves and the downy mildew - High precipitation occurred during the whole crop cycle, especially in the first months, when more than $500 \mathrm{~mm}$ of rain fell down. Monthly rain distribution, according to Metereological Station of the Universitary Campus of Gurupi (Federal University of Tocantins), was as follows: $228,330,151$, and $21 \mathrm{~mm}$, respectively from January to April 2007. Such climatic condition, particularly in the beginning of the cycle, might have favored both the gummy blight and the downy mildew, since high humidity contributes to dissemination of both sporangia and zoospores.

Regarding the gummy blight, genotypes Taslaki and Sary Juliabi were significantly the most susceptible to the leaf infection, while genotypes Perlita Busle S1, Valenciano Elíptico, Glaver, MR1, and 2526 were the less susceptible (Table 3). Genotypes M59CH4, Valenciano Elíptico, Melão Caboclo, M63A17, and Hegykô, which were clustered as less susceptible in relation to stem infection (Assay 2), were grouped among those genotypes considered as moderately resistant to leaf infection. The correlation between susceptibility in stem and leaves was previously reported in watermelon (Santos \& Café-Filho, 2005), in which a correlation value of $r=0.77$ was found between symptoms in both plant organs. The methodology of searching for resistance based on evaluating symptoms both in stem and leaves is also employed by other authors (Zhang et al., 1997; Sakata et al., 2000). Santos et al. (2004), when studying the resistance of 20 melon hybrids to the main diseases in States of Ceará and Rio Grande do Norte, observed that all genotypes were susceptible to the gummy stem blight and the downy mildew.

In spite of all genotypes being susceptible to the downy mildew, there were significant differences in susceptibility among genotypes. The highest disease severity scores came from genotypes MR1, Valenciano Amarelo, and 2526. Genotype Taslaki, for its turn, had the lowest severity score, followed by genotypes M88CH4, Prince, and Melão Caboclo (Table 3). Other authors, when studying the resistance of melon lineages to the downy mildew, found few sources of disease resistance. Cohen et al. (1995) studied the resistance of eight melon genotypes and found tolerance in lineages P22a and P6a-3.

All commercial genotypes challenged in this study were susceptible to both the gummy blight and the downy mildew. Nevertheless, there were distinct levels of susceptibility among them. The 
differential reaction points to the possibility of selecting cultivars which are likely to be less severely affected among those suitable for the market. Yet, this is a partial protection. Therefore, farmers should make use also of further integrated management measures, such as crop rotation, chemical spraying, adequate season for planting, irrigation method (avoiding leaf wetting), and balanced fertilization. In addition, it is important to implement new breeding programs and to expand the existing ones aiming at developing melon genotypes with improved levels of resistance to the gummy stem blight and the downy mildew.

\section{ACKNOWLEDGMENTS}

AC Café Filho thanks the financial support of the National Council for Scientific and Technological Development (CNPq), grant for Productivity in Research, process CNPq 306968/2006-1.

\section{REFERENCES}

ANDRIVON D. 1993. Nomenclature for pathogenicity and virulence: the need for precision. Phytopathology 83: 889-890.

BLANCARD D; LECOQ H; PITRAT M. 1996. Enfermedades de las cucurbitáceas Observar, Identificar, Luchar. Paris: INRA. $301 \mathrm{p}$.

COHEN Y; EYAL H. 1987. Downy-mildew, powdery mildew and fusarium wilt-resistant muskmelon breeding line PI 124111F. Phytoparasitica 15: 187-195.
COHEN R; SCHREIBER S; NERSON H. 1995. Response of melon breeding lines to powdery mildew, down mildew, Fusarium wilt and sudden wilt. Plant Disease 79: 616619.

NORTON JD; PRASAD K. 1967. Incorporation of recently discovered resistance to gummy stem blight, Mycosphaerella melonis (Pass.) Chiu and Walker, into edible types of muskmelon. Proceedings of Southern Agricultural Workers 62: 154.

REGO AM. 1995. Doenças causadas por fungos em cucurbitaceas. Informe Agropecuário 17: 48-54.

SAKATA Y; WAKO T; SUGIYAMA M; MORISHITA M. 2000. Screening melons for resistance to gummy stem blight. Acta Horticulturae 510: 171-178.

SANTOS AA; CRISÓSTOMO JÚNIOR; CARDOSO JW. 2004. Avaliação de híbridos de melão quanto às principais doenças nos Estados do Ceará e Rio Grande do Norte. Boletim de Pesquisa e Desenvolvimento 16: $1-14$.

SANTOS GR; FERREIRA MASV; PESSOAFILHO M; FERREIRA M; CAFE FILHO AC. 2008. Host specificity and genetic diversity of Didymella bryoniae from cucurbitaceae in Brazil. Journal of Phytopathology 156 (DOI: 10.1111/ j.1439-0434.2008.01475.x).

SANTOS GR. 2005. Biologia, epidemiologia e manejo do crestamento gomoso do caule da melancia, causado por Didymella bryoniae. Brasília: UnB. 212p. (Tese doutorado). Disponível em http:// ged1.capes.gov.br/CapesProcessos/919632ARQ/919632_5.PDF. Acessado em 15 de novembro de 2008.

SANTOS GR; CAFÉ-FILHO AC. 2006. Ocorrência do crestamento gomoso do caule em melancia no Tocantins causado por Didymella bryoniae. Fitopatologia Brasileira 31: 208-208.

SANTOS GR; CAFÉ-FILHO AC. 2005. Reação de genótipos de melancia ao crestamento gomoso do caule. Horticultura Brasileira 23: $945-950$.
SANTOS GR; CAFÉ-FILHO AC; SABOYA LMF. 2005. Controle químico do crestamento gomoso do caule na cultura da melancia. Fitopatologia Brasileira 30: 155163.

SILVA FAS; AZEVEDO CAV. 2006. A new version of the assistat-statistical assistance software. In: WORLD CONGRESS ON COMPUTERS IN AGRICULTURE, 4. Anais...Orlando-USA. p. 393-396.

SITTERLY RW; KEINATH AP. 1996. Gummy stem blight. in: ZITTER TA; HOPKINS DL; THOMAS C (eds). Compendium of Cucurbit Diseases. APS Press, St. Paul, p. 27-28.

TAKADA K. 1983. Breeding and characteristics of disease resistant melon varieties (lines "Anô no $1, \mathrm{n}^{\circ} 2$ e no 3"). Bulletin of Vegetable and Ornamental Research Station. Serie A. 11: 1-11.

THOMAS CE; COHEN Y; McCREIGHT YD; JOURDION EL; COHEN S. 1988. Inheritance of resistance to downy mildew in Cucumis melo. Plant disease 72: 33-35.

THOMAS CE. 1998. Downy Mildew. in: ZITTER TA; HOPKINS DL; THOMAS C. (eds). Compendium of Cucurbit Diseases. APS Press, St. Paul, p. 25-25.

TSUTSUMI CY; SILVA N. 2004. Screening of melon populations for resistance to Didymella bryoniae in greenhouse and plastic tunnel conditions. Brazilian Archives of Biology and Technology 47: 171-177.

ZHANG Y; KYLE M; ANAGNOSTOU K; ZITTER TA. 1997. Screening melon (Cucumis melo) for resistance to gummy stem blight in the greenhouse and field. HortScience 32: 117-121.

ZUNIGA TL; JANTZ JP; ZITTER TA; JAHN MK. 1999. Monogenic dominant resistance to gummy stem blight in two melon (Cucumis melo) accessions. Plant Disease 83: 1105-1107. 